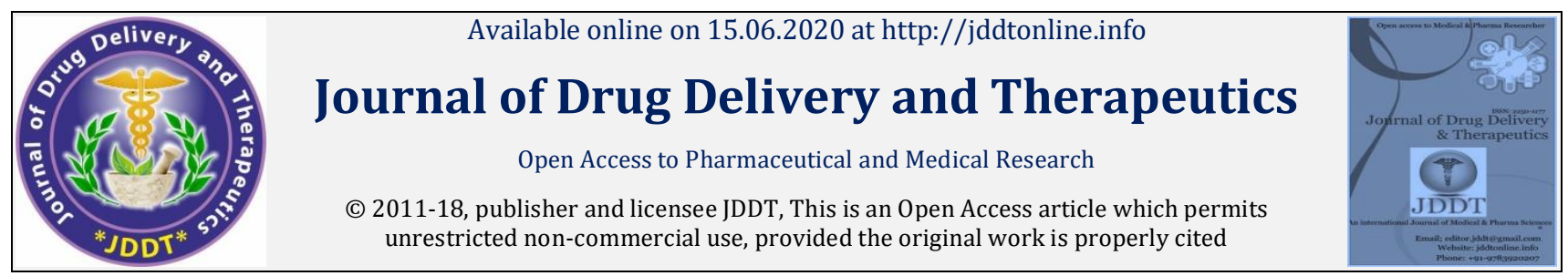

Open 1 Access

\title{
Biological Potential of Caesalpinia bonducella Seeds: A Review
}

\author{
M.J. Gadakh ${ }^{* 1}$, R.S. Jadhav ${ }^{1}$ D.N. Vikhe ${ }^{1}$ \\ Department of Pharmacognosy, Pravara Rural College of Pharmacy, Pravaranagar, A/P. Loni Taluka - Rahata, Dist. A.Nagar, (Maharashtra) India
}

\begin{abstract}
Caesalpinia bonducella L. is a medicinal plant belonging to the family Caesalpiniaceae. The plant is found in all over India. The plant is a large prickly shrub. It is popular in indigenous system of medicine like Ayurveda, Siddha, Homoeopathy and Unani. In Indian traditional plant medicine, it has been considered as an important remedy for the treatment of several diseases. The plant has been reported to possess antimalarial, antifungal, antioxidant, anticancer, antipyretic, antifertility antiviral and antimalarial etc. activities of various parts of $C$ bonducella plant. It can be concluded that $C$. bonducella can become the best source of medicine in future on various ailments with further investigations. Hence attempts have been made to take collect and compile the information about the traditional use of various parts of $C$.bonducella in various ailments, chemical constituents from various parts and the effective use of various extracts for treatment of different disea ses.
\end{abstract}

Keywords: Caesalpinia bonducella, Pharmacology, Nutritional Values.

Article Info: Received 27 March 2020; Review Completed 13 May 2020; Accepted 20 May 2020; Available online 15 June 2020

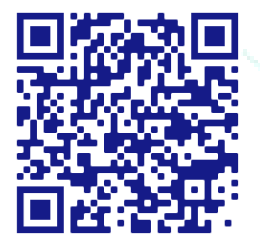

\section{Cite this article as:}

Gadakh MJ, Jadhav RS, Vikhe DN, Biological Potential of Caesalpinia bonducella Seeds: A Review, Journal of Drug Delivery and Therapeutics. 2020; 10(3-s):308-310 http://dx.doi.org/10.22270/jddt.v10i3-s.4059

\section{*Address for Correspondence:}

Dist.A.Nagar, (Maharashtra) India

\section{INTRODUCTION:}

The herbal medications play most important role in the wellbeing framework of people over the world. It is required to comprehend the particular constituents in the herbal medications which are compelling in the diverse treatments. There are numerous verifications showing the significances of herbal plants utilized in the distinctive traditional frameworks. ${ }^{1}$ It is seen that numerous restorative plants are utilized to fix ailments like stomach related issues, cardiovascular disorders, metabolic issues, liver issue, kidney issue and the disorders of central nervous systems. ${ }^{2}$ Phytochemicals are essential for the assurance of plants just as insurance of individuals from different types of diseases. ${ }^{3}$ At the most $5 \%$ of the 300,000 types of the plants worldwide have been examined experimentally for their therapeutic use. It is seen by the specialists that the developing nations rely upon the medicinal plants to fix the sicknesses especially in the district where there is the absence of hospitals. ${ }^{4}$ Caesalpinia bonducella is ordered under the group of Caesalpiniaceae. It is otherwise called $C$. bonducella Flem and C. crista Linn. Generally it is called Fever Nut, Bonduc Nut and Nicker Nut also. ${ }^{5}$ In traditional system of Indian, i.e Ayurveda, Caesalpinia bonducella (roxb) is generally utilized for its antiperiodic, antipyretic, calming, anthelmintic, antimalarial and further more for various infections like skin ailments, hydrocele, leprosy, spasms, orchitis, paralysis and analogical nervous complaints. It additionally described to have antioxidant, antibacterial, antitumor and antidiabetic actions. ${ }^{6}$ It is valuable to set up the moisturizer for the treatment of agony type cellulitis in Chinese customary medicines. ${ }^{7}$

\section{PHARMACOLOGICAL ACTIVITY:}

\section{Antioxidant Activity:}

The ethanolic concentrates of $C$. bonducella seeds contained good level of phenolic constituents and were prepared for repressing, quenching free radicals to cease the radical chain reaction, and acting as reducing agents 8 The potential antioxidant activity was confirmed by DPPH for ethanol leaf extract of Caesalpinia bonduc. The results demonstrate that the antioxidant activity may add to the cytotoxic nature of the plant which may be the future study to be carried out. 9 Chloroform extract of Caesalpinia bonducella seeds shows antioxidant activity 10

\section{Anticancer:}

Caesalpinia bonducella is compared with already established anti-cancer drugs, the binding energy was highly comparable as well as interactions with the proteins. They further possess good ADMET characteristics, indicating 
these phytochemical isolates can likewise be viewed as safe and thus be further developed into active commercial anticancer drugs. ${ }^{11}$

\section{Antiviral Activity:}

An ethanolic extract of the root and stem exhibited activity against the Vaccinia virus. ${ }^{12}$ Anti-Amyloidogenic/ Alzheimer's disease Caesalpinia leaf aqueous extract has anti-amyloidogenic potential. Study showed aqueous extract of Latakaranj could inhibit the Abeta aggregration from monomers and oligomers and able to disintegrate the preformed fibrils. ${ }^{13}$

\section{Antipyretic Activity:}

The Caesalpinia bonducella seed kernel extract showed marked antipyretic action against Brewer's yeast-initiated pyrexia in rats. The concentrate had good central analgesic action in hot plate and tail flick methods. In conclusion, the study suggested that the ethanolic extract of Caesalpinia bonducella seed kernel has strong antipyretic and antinociceptive activities and thus, approves its utilization in the treatment of pain and pyretic disorders. ${ }^{14}$ The seed oil of C. bonducella is good source for antipyretic agent. 15

\section{Antifungal Activity}

The aqueous and ethyl acetic acid extracts of C.bonducella seeds show high to moderate antifungal activity against Alternaria solani, Fusarium oxysporum, Candida albicans and Aspergillus niger. It indicates $C$. bonducella possesses a potential to control important fungal pathogens. It might be because of the presence of a few bioactive molecules that include oils, saponins, sterols, glycosides, tannins, alkaloids, phenols, resins and flavonoides in seeds of $C$. bonducella. ${ }^{16}$

\section{Antifilarial Activity:}

C.bonducella- seed part demonstrated microfilaricidal, macrofilaricidal and female-sterilizing adequacy against $\mathrm{L}$. sigmodontis and microfilaricidal and female-sterilizing viability against B. malayi in animal models, demonstrating the capability of this plant in giving a lead to new antifilarial tranquilize development. ${ }^{17}$

\section{Antimalarial Activity:}

Cold ethanol, aqueous and hot ethanol extracts of seeds of Caesalpinia bonducella showed 56\%, 65\% and 76\% growth inhibition of $\mathrm{P}$. falciparum respectively. It supports antimalarial activity of C. bonducella. ${ }^{18}$

\section{Neuroprotective Activity:}

The methanolic and aqueous extract of Caesalpinia bonducella (Roxb) has shown significantly neuroprotective activity compare to the standard drug (Vitamin E). Different extracts of the Caesalpinia bonducella (Roxb) exerts remarkable antioxidant activity due to possible multiple effects involving significant protection against the oxidative damage, which might be credited to its protective activity on lipid peroxidation and resistance adding to the assurance against oxidative damage. ${ }^{19}$

\section{Diuretic Activity:}

Both the aqueous and methanol concentrates of $C$. bonducella demonstrated a dose-dependent rise in urine discharge. As for the aqueous concentrate, the maximum increase in urinary excretion was created at $300 \mathrm{mg} / \mathrm{kg}$ compared with the methanol extract. Study provide a quantitative basis to explain the traditional use of $C$. bonducella as a diuretic agent in Moroccan population. 20

\section{Anti-fertility Activity:}

The administration of test drug Caesalpinia bonducella exhibite potent antiimplantation activity, anti-estrogenic activity, abortion and anti-estrogenic activity, antiovulatery activity. Caesalpinia bonducella Linn. Roxb. Root bark (ERb) can be used for induction in sterility i.e. It can be used as anti-fertility agent. ${ }^{21}$

\section{Nutritional values:}

C. bonducella has been reported to contain the nutrients such as crude fibre 12.79 - $14.07 \%$, Protein 18.65 20.32\%, Fat 6.54 - 7.23\%, Carbohydrate 16.91- 18.56\%, Food energy (Kcal/100g) 376.27 - 402.12, Calcium 0.150 - $0.184 \%$, Phosphorus 0.17 - $0.22 \%$, Sodium 0.07 $0.08 \%$, Iron $0.22-0.5 \%$, Vitamin C $0.016-0.043$ (IU/g) and Vitamin A 416.75 - 700.14 (IU/g) 22

\section{REFERENCES:}

1. Singh V, Raghav PK. Review of pharmacological properties of Caesalpinia bonduc L. International Journal of Medicinal and Aromatic Plants 2012; 3(2):514-530.

2. Khan N, Kumar S, Singh RP, Dhankhar N. A Pharmacognostic and Pharmacological Overview on Caesalpinia bonducella. Research Journal of Pharmaceutical, Biological and Chemical Sciences 2012; 3(1):480-496.

3. Dhanasekaran M. Phytochemical screening of Ardisia blatteri gamble: An endemic plant of Southern Western Ghats, Tamilnadu, India. Int. Res. J. Pharm. 2016; 7(2):31-35 http://dx.doi.org/10.7897/2230-8407.07216

4. Olutayo O, Michael A, John AA, Olusola A. Antimicrobial activity and Elemental analysis of Cassia siberiana leaves Using Atomic Absorption Spectrometer. Journal of Natural Product and Plant Resources 2012; 2(1):9-18.

5. Khare CP. Indian Medicinal Plants, an Illustrated Dictionary. New York: Springer Science+ Business Media; 2007. p. 107- 108.

6. Ali A, Venkat Rao N, Md. Shalam, Shivaraj Gouda T and Shantakumar SM. Anticonvulsive effect of seed extract of Caesalpinia bonducella (roxb.). Iranian Journal of Pharmacology \& Therapeutics 2009; 8(2):51-55.

7. Ma Suqiao. Traditional Chinese medicinal lotion for treating paintype cellulitis and its preparation method. Faming Zhuanli Shenqing 2012; CN 102743698 a 20121024.

8. Shukla S, Mehta A, John J, Singh S, Mehta P, Vyas SP; Antioxidant activity and total phenolic content of ethanolic extract of Caesalpinia bonducella seeds; 2009 Elsevier Ltd. All rights reserved. doi:10.1016/j.fct.2009.04.040.

9. Veerabathran SK, Janaky S., Sekar T; Antioxidant Status of Leaves of Caesalpinia Bonduc; International Journal of Pharmaceutical Applications ISSN 0976-2639. Vol 2, Issue 4, 2011, pp 262-266.

10. Sachan NK, Shikhar Verma, Anupam K Sachan And Hussain Arshad; An investigation to antioxidant activity of Caesalpinia bonducella seeds; Annals Of Pharmacy And Pharmaceutical Sciences 2010; 1(2):88-91.

11. Iheagwam FN, Ogunlana OO, Ogunlana OE, Isewon I, Oyelade J; Potential Anti-Cancer Flavonoids Isolated From Caesalpinia bonduc Young Twigs and Leaves: Molecular Docking and In Silico Studies, Bioinformatics and Biology Insights, 2019; 13:1-16.

12. Dhar ML, Dhar MM, Dhawan BN, Mehrotra BN, and Ray C; Screening of Indian plants for biological activity, Indian Journal of Experimental Biology, 1968; 6(4):232-247.

13. Ramesh BN, Indi SS and Rao KSJ. Anti-amyloidogenic Property of Leaf Aqueous Extract of Caesalpinia Crista, Neuroscience Letters 3/2010, DOI:1016/j.neulet.2010.03.062.

14. Archana P., Tandan S. K., Chandra S., \& Lal. J. Antipyretic and analgesic activities ofCaesalpinia bonducella seed kernel extract. Phytotherapy Research, 2005; 19(5):376-381. doi:10.1002/ptr.1339.

15. Shukla S, Mehata A, Mehata P, Vyas PS, Shukla S, Bajpai VK. Studies on anti-inflammatory, antipyretic and analgesic properties of Caesalpinia bonducella F. seed oil in experimental animal models. Food and Chemical Toxicology 2010; 48(1): 61-64

16. Shukla S, Mehta P, Mehta A, Vyas SP, Bajpai VK. Preliminary phytochemical and antifungal screening of various organic 
extracts of Caesalpinia bonducella seeds. Romanian Biotechnological Letters 2011; 16(4): 6384-6389.

17. Gaur R.L., Sahoo M.K., Dixit S., Fatma N., Rastogi S., Kulshreshtha D.K., Chatterjee, R.K., Murthy, P.K. 2008. Antifilarial activity of Caesalpinia bonducella against experimental filarial infections. Indian Journal of Medicinal Research, 128: 65-70.

18. Irshad S, Mannan AB. Antimalarial activity of three Pakistani medicinal plants. Pakistan Journal of Pharmaceutical Sciences 2011; 24(4): 589-591.

19. Hosamani SD, Inamdar SS, Pandey RRK, Kulkarni PP, Vatikuti $\mathrm{H}$; Neuroprotective Activity of Seeds of Caesalpinia
Bonducella (Roxb) In Oxidative Stress Induced Rats. World Journal of Pharmaceutical Research, 2016; 5(6):1444-1457.

20. Khedkar, A., Mandavkar, Y. D., Shinde, G., Khalure, P., \& Dere, P. Diuretic effect of Caesalpinia bonduc in rats. Bangladesh Journal of Pharmacology, 2011; 6(1). doi:10.3329/bjp.v6i1.8487.

21. Khedkar Ajay Sukhdev, Mandavkar Yuvaraj Dhondiram, Khalure Pallavi R, Chougule nilesh Balasaheb. Antifertility activity of root bark of Caesalpinia bonduc linn. roxb. in female albino rats. Pharmacologyonline. 2011; 3:34-41.

22. RavikanthK; Kanaujia A; Thakur D; Sharma A. Int J Adv Pharm Biol Chem., 2014; 3(3):698-702. 